\title{
New data on the Afrotropical Xantholinini. 2. Six new species of Metocinus Cameron, 1950 (Coleoptera, Staphylinidae)
}

\author{
288th contribution to the knowledge of Staphylinidae
}

\author{
Arnaldo BORDONI \\ Museo di Storia Naturale dell'Università di Firenze, Sezione di Zoologia "La Specola” \\ Via Romana 17, I-50125 Firenze, Italy;e-mail: arnaldo.bordoni@fastwebnet.it
}

\begin{abstract}
Six species of the genus Metocinus, which is one of the most characteristic and widespread in central Africa, i.e. M. szujeckii n. sp. (Zaire), M. angustus n. sp. (Uganda), M. ibadan n. sp. (Nigeria), M. ugandensis n. sp. (Uganda), M. capitatus n. sp. (Uganda), M. uzungwa n. sp. (Tanzania) are described and illustrated. With the six species here described, the taxa of this genus, endemic to Africa, add up to 88 .
\end{abstract}

Key words: Coleoptera, Staphylinidae, Xantholinini, Metocinus, new species, Africa

\section{INTRODUCTION}

This is the second updating to the knowledge of the Afrotropical Xantholinini (the first is dedicated particularly to some new species of Notolinopsis Casey, 1906 sensu meo from South Africa (Bordoni 2017)), since publication of the revision (Bordoni 2016) of the species of that continent. This revision is part of a project to study the Xantholinini of the whole world and follows the revisions of the species of the Oriental Region (Bordoni 2002), the Australian one (Bordoni 2005), New Zealand (Bordoni 2005a), New Guinea (Bordoni 2010) and Pacific Islands (Bordoni 2013). They are accompanied by 33 contributions on the species of China and Japan, 45 updates dedicated to the same Oriental Region, and 10 contributions on the Australasian Region, published over the past 15 years. The next objective is the revision of the species of Madagascar and neighboring islands.

The genus Metocinus Cameron is one of the most characteristic genera of the Afrotropical fauna, endemic of the area where it is represented by as many as 82 species to which must be added those described here for a total of 88 species. The aedeagus of this genus is particular, oblong, consisting of very thin, transparent membrane, composed of three telescoped parts because the component parts fit into one another, while being connected to one other (cfr Bordoni 2016).

\section{MATERIAL AND METHODS}

The specimens studied, the subject of these pages, belong to some European museums and in particular to the Manchester Museum, Great Britain (MMUE) and to the Zoological Museum in Copenhagen, Denmark (ZMKU). Some specimens from my personal collection (cB) are added. The examination of the specimens was done through a Wild M5A binocular and Optika B-293 tri-ocular microscope. 


\section{Metocinus szujeckii n. sp.}

(Figs 1-3, 19)

Examined material. Holotype ${ }^{\Uparrow}$ : Zaire, N Kivu, Volcan Nyirangongo, 2700 m, leg. G. Carpaneto \& S. Zoia, 17 Jul 1990 (cB).

Description. Length of body $5.3 \mathrm{~mm}$; from anterior margin of head to posterior margin of elytra: $2.5 \mathrm{~mm}$. Body slender and shiny, without microsculpture, reddish brown with pale brown antennae and legs. Head ovoid elongate, narrow, with moderately rounded sides and widely rounded posterior angles. Eyes small, slightly protruding. Surface of head with fine, scattered punctation. Pronotum narrow, as long and wide as head, with oblique anterior margins, widely rounded anterior angles, not sinuate sides. Surface with dorsal series of 7-8 punctures and oblique, lateral series of 5-6; some other punctures near the anterior angles. Elytra slightly dilated posteriad, as long as pronotum, wider than it, with rounded humeral angles. Surface with two series of wide but superficial puntures near the suture and two lateral series of fine, spaced punctures. Abdomen with fine, spaced punctation.

Tergite and sternite of the male genital segment as in Figs 1-2. Aedeagus (Fig. 3) $0.74 \mathrm{~mm}$ long, with long parameres and short, basal inner sac covered with rounded scales.

Etymology. The species is dedicated to my friend and colleague Prof. Andrzej Szujecki (1929-2017), specialist in Staphylinidae, in memoriam.

Distribution. The species is known only from the type locality in Congo.

Remarks. Metocinus szujeckii n. sp. is closely related to M. elegantissimus Bordoni, 2016 from Burundi, from which it differs by longer body, shape of head-pronotum, punctation of head, dorsal and lateral series of punctures on pronotum, and aedeagus.

\section{Metocinus angustus n. sp.}

(Figs 4-6, 20)

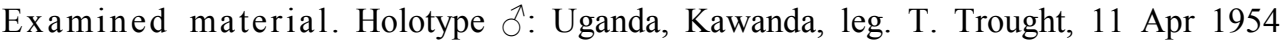
(MMUE).

Description. Length of body $5 \mathrm{~mm}$; from anterior margin of head to posterior margin of elytra: $2.6 \mathrm{~mm}$. Body shiny, without microsculpture, apart from traces of polygonal microreticulation on abdomen. Uniformly reddish brown. Characterized by the narrow body, with sub-rectangular forebody. Head sub-rectangular, with slightly rounded sides and widely rounded posterior angles. Eyes small and not very prootruberant. Surface of head with fine, scattered punctation. Pronotum robust, a little longer than head, as wide as it, with oblique anterior margins, almost not sinuate sides. Surface with dorsal series of 7-8 punctures and lateral series of 5-6 fine punctures. Elytra sub-rectangular, not dilated posteriad, with subrectilinear and sub-parallel sides, and little-marked humeral angles. Surface with fine, scattered punctation, arranged in several series. The punctures with short, yellowish setae. Abdomen with fine, sparse punctation.

Tergite and sternite of the male genital segment as in Figs 4-5. Aedeagus (Fig. 6) $1.1 \mathrm{~mm}$ long, with narrow parameres; inner sac with a dark distal area next to a dark mass composed of large scales and 2 evident spines; on right portion is a series of very fine spinulae, followed, in the median portion of the sac by an arcuate series of rounded scales.

Etymology. The specific epithet is the Latin angustus- $a$ - um (narrow), in relation to the narrow body

Distribution. The species is known only from the type locality in Uganda.

Remarks. This species is rather isolated among the congeners in the structure of the inner sac of the aedeagus. The specimen, in very poor conditions, was collected at light. 


\section{Metocinus ibadan n. sp.}

(Figs 7-9, 21)

Examined material. Holotype $\delta^{\lambda}$ : Nigeria, Ibadan, leg. J. Gregory, Feb 1953 (MMUE).

Description. Length of body $5 \mathrm{~mm}$; from anterior margin of head to posterior margin of elytra: $2.9 \mathrm{~mm}$. Body brownish-black with light brown elytra and abdomen. Characterized by the very large and protruding eyes. Pronotum longer and narrower than head. Head with fine and scattered punctation. Pronotum with dorsal series of 4 superficial punctures and lateral series of 3-4 punctures. Elytra large, flat, dilated posteriad, longer and wider than pronotum, with rounded humeral angles. Surface with very fine punctation, arranged in three series, one juxtasutural, one median and one lateral. Scutellum particularly large.

Tergite and sternite of the male genital segment as in Figs 7-8. Aedeagus (Fig. 9) long and narrow, $1.1 \mathrm{~mm}$ long, with short and robust parameres; inner sac with two series folded on itself of spines and scales.

Etymology. The specific epithet is the name of the type locality, as a noun in apposition.

Distribution. The species is known only from the type locality in Nigeria.

Remarks. This species is closely related to M. zambianus Bordoni 2016 from Zambia and M. fluviatilis Bordoni 2016 from Congo in the structure of the inner sac of the aedeagus.

The specimen is in very poor conditions, without median and posterior legs.

Metocinus ugandensis n. sp.

(Figs 10-12, 22)

Examined material. Holotype $\widehat{\jmath}$ : Uganda, Soroti, Serere, leg. J. C. Davis, 8 Jul 1963 (MMUE); paratypes: same date, $2 \hat{\jmath}$ (MMUE), $1 \hat{\partial}, 1 \uparrow(\mathrm{cB})$.

Description. Length of body $5.3 \mathrm{~mm}$; from anterior margin of head to posterior margin of elytra: $3.2 \mathrm{~mm}$. Head light reddish-brown; pronotum, elytra and abdomen yellowish-orange; last 3 abdominal segments infuscate. Similar to M. cephalicus Bordoni 2016 from which differs by the broader head, smaller eyes, darker head and last abdominal segements. Head with fine, transverse micro-striation and finer and sparser punctation. Eyes very protruberant, large but smaller than those of $M$. cephalicus. Pronotum wider anteriad and slighter shorter than head, with wider and deeper punctures of dorsal series. Elytra longer with smaller scutellum.

Tergite and sternite of the male genital segment as in Figs 10-11. Aedeagus (Fig. 12) 0.7 $\mathrm{mm}$ long, broad, with massive distal structure and short and robust parameres; inner sac differently structured, with 2 series of small spines and scales.

Etymology. The specific epithet is a Latin adjective derived from the geographic name Uganda and the suffix -ensis (denoting place).

Distribution. The species is known only from the type locality in Uganda.

Remarks. This species belongs to the allardi-group, and is related to $M$. cephalicus Bordoni, 2016 and M. pseudocephalicus Bordoni, 2016 from Congo in the peculiar shape of head.

\section{Metocinus capitatus n. sp.}

(Figs 13-15, 23)

Examined material. Holotype đ̂: Uganda, Kibale Forest, leg. H. Gonget, Dec 1972 (ZMKU); paratype: 1 q: Nigeria, Ibadan, leg. H. Stenholt Clauser, Jan-Jul 1954 (cB).

Description. Length of body $4.9 \mathrm{~mm}$; from anterior margin of head to posterior margin of elytra: $2.7 \mathrm{~mm}$. Body shiny, reddish-brown with orange elytra; antennae brown, legs brown 
light. Head large, massive, sub-quadrangular, with almost rectilinear sides and moderately rounded posterior angles. Eyes very large and protruding. Surface of head with wide, scattered punctation. Pronotum massive, longer than head, as wide as it. Surface with dorsal series of 57 punctures and lateral series of 3 anterior punctures. Elytra large, longer and wider than pronotum, dilated posteriad, with rounded humeral angles. Surface with fine and sparse punctation, arranged in several series. Abdomen with superficial, transverse micro-striation and fine, very scattered punctation.

Tergite and sternite of the male genital segment as in Figs 13-14. Aedeagus (Fig. 15) 0.96 $\mathrm{mm}$ long, particularly membranous, with large distal structure and robust parameres; inner sac with a series of large, sub-rectangular scales, followed by fine scales.

Etymology. The specific epithet is the Latin capitatus- $a$ - um (with head), in relation to the massive head.

Distribution. The species is known from the type localities in Uganda and Nigeria.

Remarks. This species presents some characters that differ from those of the genus but not similar to those of the Afrotropical genus Amharina Bordoni, 2016 with similar structure of the aedeagus: maxillary palpi with longer segments than those of the other species, and superior epipleural line of pronotum apparently missing anteriad. The right anterior tarsus and the median right leg are missing.

\section{Metocinus uzungwa n. sp.}

(Figs 16-18, 24)

Examined material: Holotype $\widehat{\jmath}$ : Tanzania, Uzungwa Mts, Mwanihana forest above Sanje, 1800 m, pitfall trap, 18 Aug 1982 (ZMKU).

Description. Length of body $4.9 \mathrm{~mm}$; from anterior margin of head to posterior margin of elytra: $2.7 \mathrm{~mm}$. Body shiny, reddish brown. Head sub-rectangular, slightly dilated anteriad, with moderately rounded sides and rounded posterior angles. Eyes medium-sized and protruding. Surface of head with very fine, scattered punctation. Pronotum massive, shorter than head, as wide as it, with oblique anterior margins, widely rounded anterior angles, not sinuate sides. Surface with dorsal series of 8-9 punctures and lateral series of 4-5 irregular punctures. Elytra large, longer and wider than pronotum, dilated posteriad, with rounded humeral angles. Surface with very fine punctation, arranged in several series. Abdomen with very fine punctation in several series.

Tergite and sternite of the male genital segment as in Figs 16-17. Aedeagus (Fig. 18) $1 \mathrm{~mm}$ long, membranous in the basal portion, with long distal structure, narrow parameres; inner sac with very fine spinulae, followed by very small scales.

Etymology. The specific epithet is the name of the type locality, as a noun in apposition

Distribution. The species is known for the type locality in Tanzania.

Remarks. This species, due to the inner sac of the aedeagus, can be included in the meridionalis sub-group, next to M. bambusianus Bordoni, 2016 from Congo. 

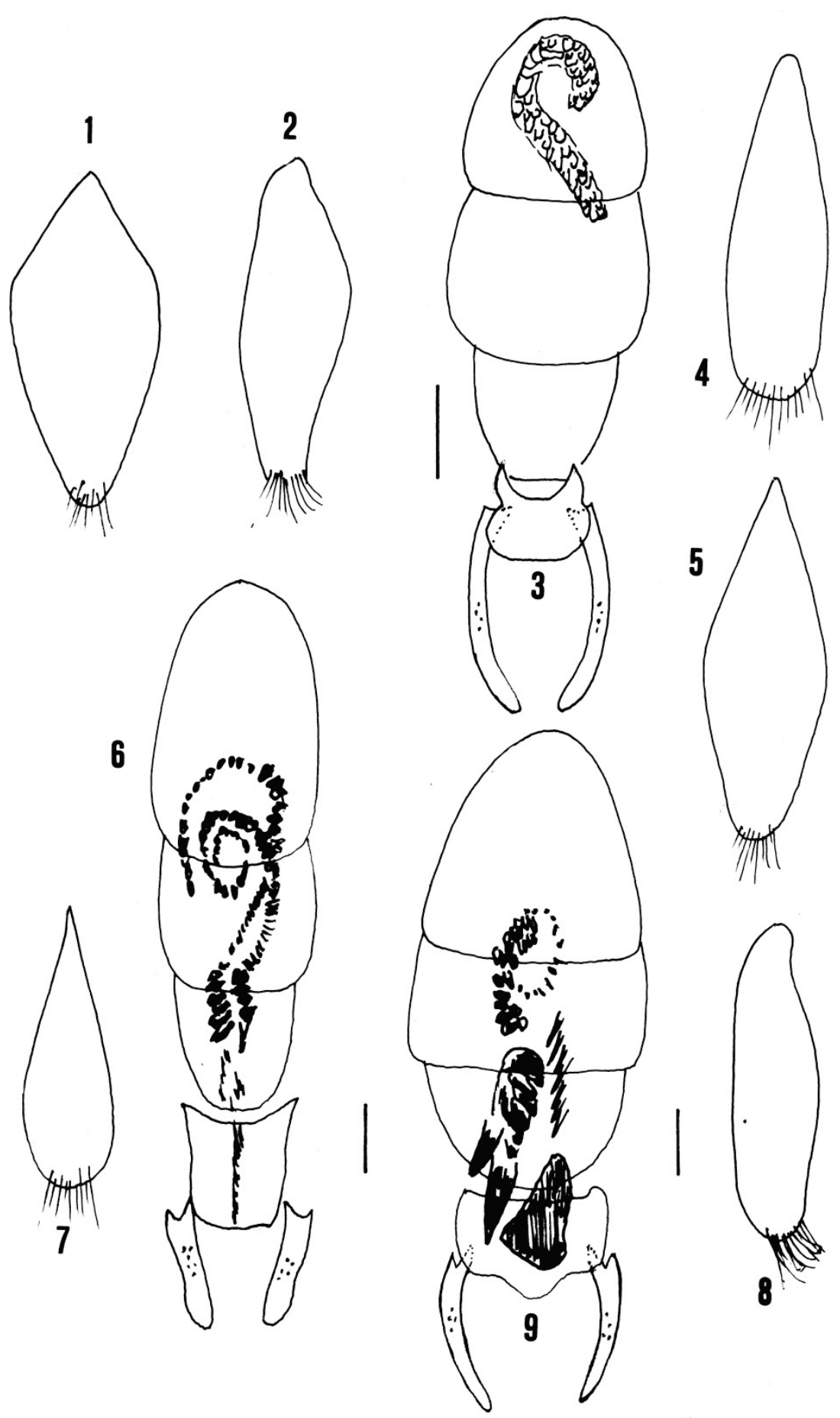

Figs 1-9: Tergite of the male genital segment, sternite of the same, aedeagus of Metocinus szujeckii n. sp. (1-3), Metocinus angustus n. sp. (4-6), and Metocinus ibadan n. sp. (7-9) (scale bar: $0.1 \mathrm{~mm}$ ). 


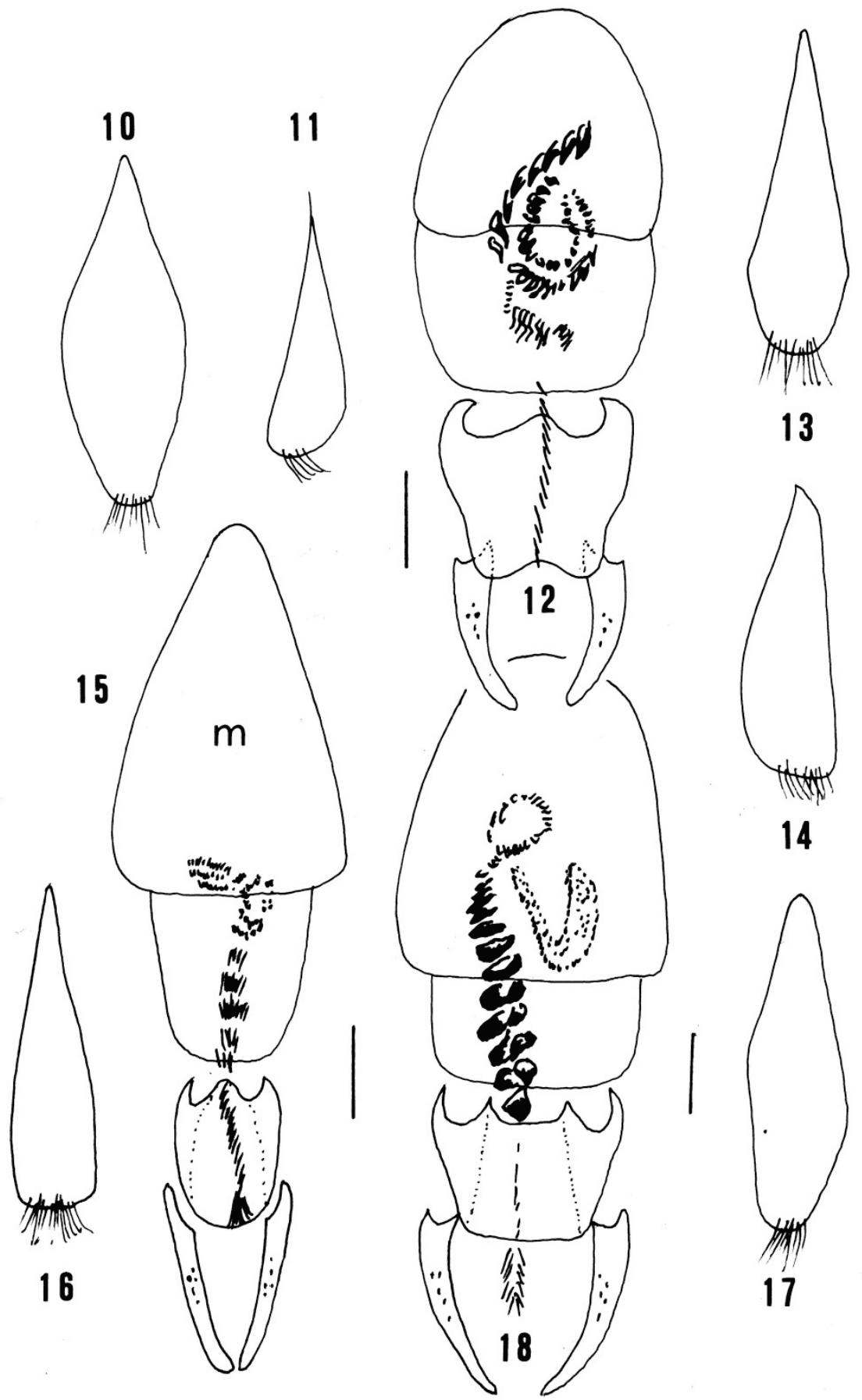

Figs 10-18: Tergite of the male genital segment, sternite of the same, aedeagus Metocinus ugandensis $\mathrm{n} . \mathrm{sp} .(10-12)$, Metocinus capitatus n. sp. (13-15) and Metocinus uzungwa n. sp. (16-18) (scale bar: $0.1 \mathrm{~mm}$ ). 


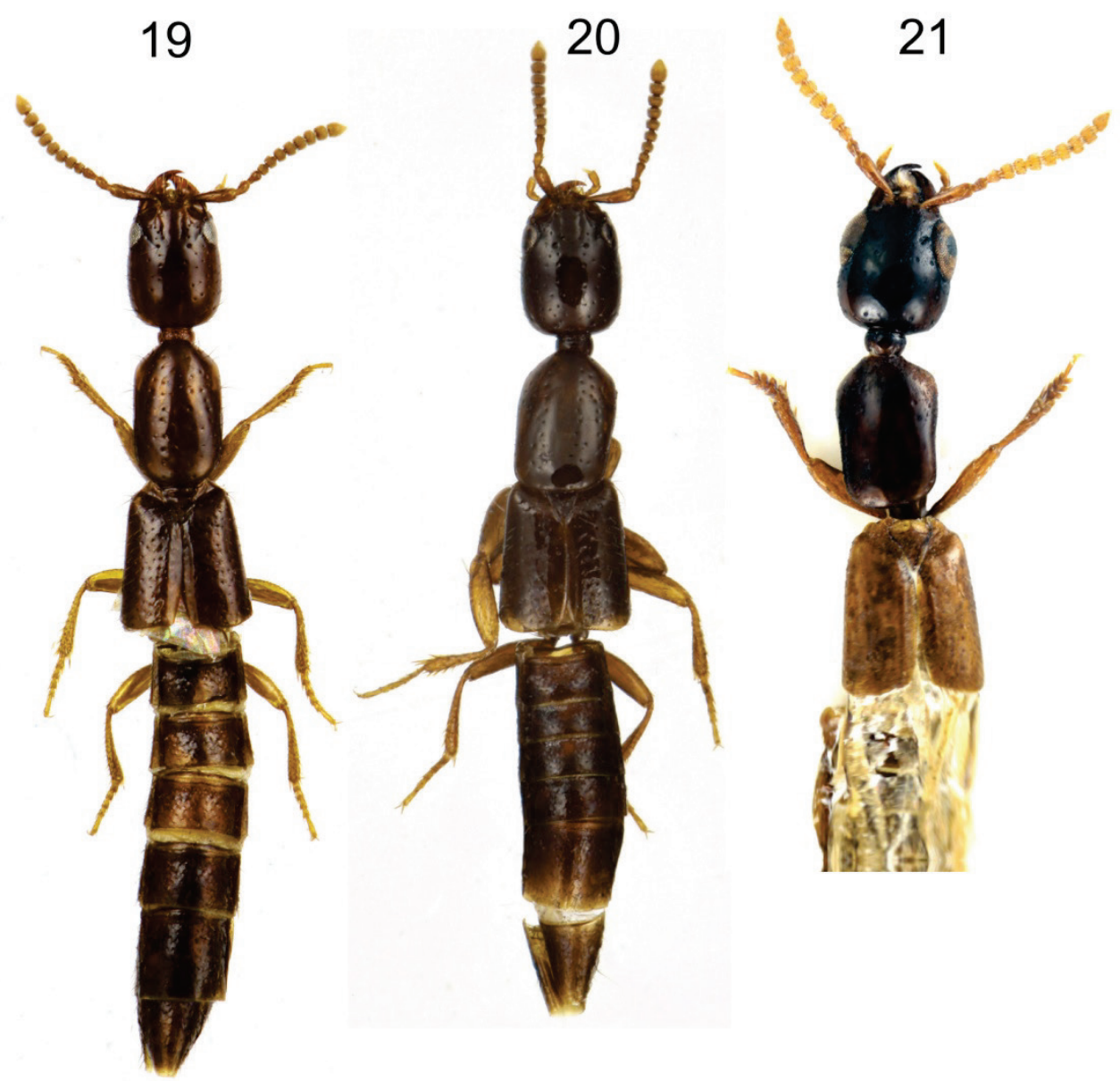

Figs 19-21: Habitus of Metocinus szujeckii n. sp. (total lenght: $5.3 \mathrm{~mm}$ ) (19), M. angustus n. sp. (total lenght: $5 \mathrm{~mm}$ ) (20), and M. ibadan n. sp. (total lenght: $5 \mathrm{~mm}$ ) (21). Photos by S. Cuoco.

\section{CORRECTION}

The holotypes of the species from South Africa described in the first supplement (Bordoni 2017) to the revision of the Afrotropical Xantholinini (Bordoni 2016), originally indicated as preserved in the Janak's collection, are now all preserved in the Transvaal Museum of Pretoria.

\section{ACKNOWLEDGEMENTS}

I thank my friends and colleagues for providing the material to this study: Dr. Dmitri Logunov (The Manchester Museum, University of Manchester, UK) and Dr. Alexey Solodovnikov (Natural History Museum of Denmark, University of Copenhagen, Denmark). My thanks also to Guillaume de Rougemont (Oxford) for checking the English, Silvio Cuoco (Livorno, Italy) and Alexey Solodovnikov for the nice photos, and the anonymous referees for the suggestions. 


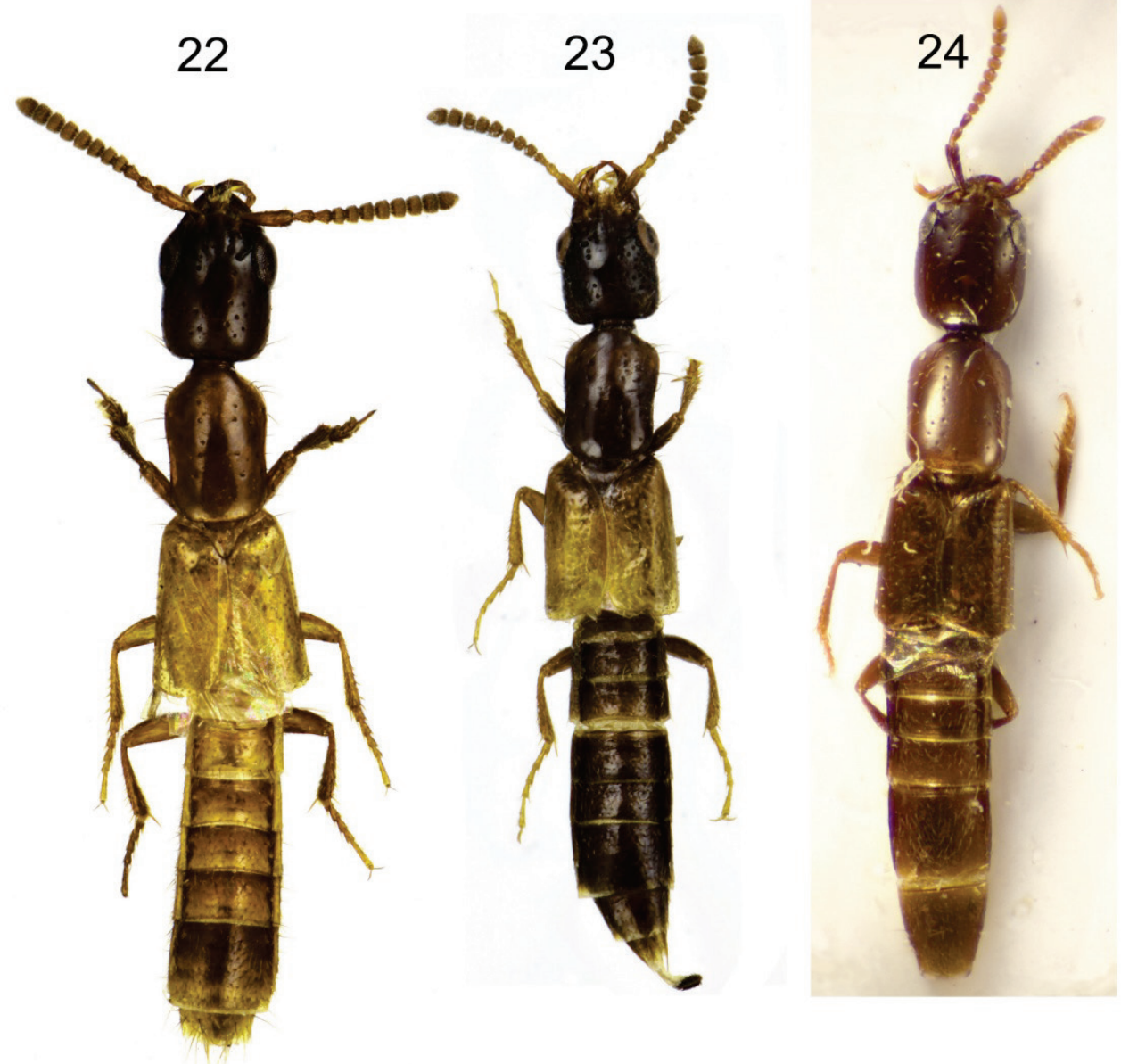

Figs 22-24: Habitus of Metocinus ugandensis sp. n. (total lenght: $5.3 \mathrm{~mm}$ ) (22), M. capitatus sp. n. (total lenght: $4.9 \mathrm{~mm}$ ) (23), and M. uzungwa sp. n. (total lenght: $4.9 \mathrm{~mm}$ ) (24). Photos 22, 23 by S. Cuoco, photo 24 by A. Solodovnikov.

\section{REFERENCES}

Bordoni A. 2002. Xantholinini della Regione Orientale (Coleoptera: Staphylinidae). Classificazione, filogenesi e revisione tassonomica. Monografie del Museo regionale di Scienze naturali Torino 33: 1-998 pp.

Bordoni A. 2005. Revision of the Xantholinini of Australia (Coleoptera: Staphylinidae). Monografie del Museo regionale di Scienze naturali Torino 42: 435-614.

Bordoni A. 2005a: Revisione degli Xantholinini della Nuova Zelanda (Coleoptera, Staphylinidae). Bollettino del Museo regionale di Scienze naturali Torino 22 (2004, 2): 329-442.

Bordoni A. 2010. Revisione degli Xantholinini della Nuova Guinea e delle isole austromalesi (Coleoptera, Staphylinidae). Bollettino del Museo regionale di Scienze naturali Torino 27 (2009, 2): 253-635.

BORDONI A. 2013. Revisione degli Xantholinini della sottoregione polinesiana (Coleoptera Staphylinidae). Memorie della Società entomologica italiana 90 (1): 1-58.

Bordoni A. 2016. Revision of the Afrotropical Xantholinini (Coleoptera, Staphylinidae). Biodiversity Journal 7 (4): 389-894.

Bordoni A. 2017. New data on the Afrotropical Xantholinini. 1. New species from South Africa in the Janak collection (Coleoptera, Staphylinidae). Linzer biologische Beiträge 49 (2): 1233-1243.

CAmeron M. 1950. Staphylinidae (Coleoptera Polyphaga). Explorations du Parc National Albert. Mission G. F. de Witte (1933-1935). Fascicule 59: 1-85.

CASEY T. L. 1906. Observations on the staphylinid groups Aleocharinae and Xantholinini chiefly of America. Transactions of the Academy of Sciences of St. Louis 16 (6): 125-434. 


\section{STRESZCZENIE}

[Nowe dane o afrotropikalnych Xantholinini. 2. Sześć nowych gatunków Metocinus Cameron, 1950 (Coleoptera, Staphylinidae)]

To jest drugie uzupełniające opracowanie Xantholinini (Coleoptera, Staphylinidae, Xantholininae) regionu Afrotropikalnego po rewizji plemienia (Bordoni 2016). Praca zawiera opisy sześciu gatunków należących do rodzaju Metocinus Cameron, 1950, który jest jednym z najbardziej charakterystycznych i szeroko rozprzestrzenionych w Afryce na południe od Sahary, szczególnie w centralnych regionach kontynentu. Przedstawiciele rodzaju Metocinus są drobnymi kusakami średnich rozmiarów i żyją na obszarach wyżynnych średniej wysokości w humusie lasów bambusa i Hagenia. Ich identyfikacja nie jest łatwa, gdyż są bardzo podobne wielkością, barwą i ogólnie kształtem ciała. Z tego powodu badania męskiego narządu kopulacyjnego (aedeagus) są niezbędne, gdyż identyfikacja każdego gatunku opiera się na szczegółach morfologii tego narządu oraz charakterystycznym ułożeniu szczecin, kolców i płytek. Łącznie z sześcioma opisanymi tu gatunkami, endemiczny dla Afryki rodzaj Metocinus obejmuje obecnie 88 gatunków, w większości opisanych we wspomnianej rewizji. 